\title{
Tindak Pidana Kekerasan Dalam Proses Belajar Mengajar Ditinjau Dari Perspektif Hukum Pidana Dan Undang-Undang Nomor 14 Tahun 2005 Tentang Guru Dan Dosen
}

\author{
Aan Hardiansyah ${ }^{*}$, Akhmad Khisni $^{* *}$, Jawade Hafidz ${ }^{* * *}$ \\ * Wakapolres Polres Jepara, Mahasiswa Program Magister (S2) Ilmu Hukum Fakultas Hukum \\ UNISSULA Semarang, email dyas.maia@gmail.com \\ ** Dosen Fakultas Hukum UNISSULA Semarang \\ ${ }^{* * *}$ Dosen Fakultas Hukum UNISSULA Semarang
}

\begin{abstract}
This research entitled Criminal Violence in Teaching and Learning Process Viewed From Criminal Law Perspective Law Number 14 Year 2005 About Teachers and Lecturers. The purpose of this study: 1) To know and analyze the criminal acts in teaching and learning process in the perspective of criminal law and Law no. Law No. 14 Year 2005 on Teachers and Lecturers. 2) To know and analyze the weaknesses of criminal acts in teaching and learning process in the perspective of criminal law and Law no. Law No. 14 Year 2005 on Teachers and Lecturers. 3) To find out the solution of criminal acts in teaching and learning process in the perspective of criminal law and Law no. Law No. 14 Year 2005 on Teachers and Lecturers.

Result of the research: 1) Provision of physical sanctions by teachers to learners in the perspective of criminal law is not a criminal offense and can not be accounted for criminal, as such a physical sanction is a means to improve education and discipline of learners. 2) In today's era of many complaints of teacher violence against students, teachers who provide physical sanctions to students in school is not a criminal offense and can not be held criminally liable as a physical sanction just as a means to educate and discipline students and physical sanctions given in the corridor and fairness limits. 3) The solution of crime in teaching and learning process is: a. Apply nonviolent education. b. Encourage or develop humanization of education. c. The punishment provided correlates with the child's actions. d. Equip teachers with knowledge insights. e. Counseling. f. Immediately provide help to anyone experiencing acts of violence.
\end{abstract}

Keywords : Crime, Violence, Teacher And Lecturer

\section{ABSTRAK}

Penelitian ini berjudul Tindak Pidana Kekerasan Dalam Proses Belajar Mengajar Ditinjau Dari Perspektif Hukum Pidana Undang-Undang Nomor 14 Tahun 2005 Tentang Guru Dan Dosen. Tujuan Penelitian ini : 1) Untuk mengetahui dan menganalisis tindak pidana dalam proses belajar mengajar dalam perspektif hukum pidana dan Undang-Undang No. 14 Tahun 2005 tentang Guru dan Dosen. 2) Untuk mengetahui dan menganalisis kelemahan-kelemahan tindak pidana dalam proses belajar mengajar dalam perspektif hukum pidana dan Undang-Undang No. 14 Tahun 2005 tentang Guru dan Dosen. 3) Untuk mengetahui solusi tindak pidana dalam proses belajar mengajar dalam perspektif hukum pidana dan Undang-Undang No. 14 Tahun 2005 tentang Guru dan Dosen.

Hasil Penelitian : 1) Pemberian sanksi fisik oleh guru kepada peserta didik dalam prespektif hukum pidana bukan merupakan tindak pidana dan tidak dapat dipertanggungjawabkan pidana, semampang sanksi fisik tersebut merupakan sarana untuk meningkatkan edukasi dan kedisiplinan peserta didik. 2) Pada era sekarang ini banyak aduan kekerasan guru terhadap peserta didik, guru yang 
memberikan sanksi fisik kepada peserta didik di sekolah bukan merupakan tindak pidana dan tidak dapat dimintai pertanggungjawaban pidana semampang sanksi fisik tersebut hanya sebagai sarana untuk mendidik dan mendisiplinkan peserta didik serta sanksi fisik yang diberikan dalam koridor dan batas kewajaran. 3) Solusi tindak pidana dalam proses belajar mengajar adalah : a. Menerapkan pendidikan tanpa kekerasan. b. Mendorong atau mengembangkan humanisasi pendidikan. c. Hukuman yang diberikan berkorelasi dengan tindakan anak. d. Membekali guru dengan wawasan pengetahuan. e. Konseling. f. Segera memberikan pertolongan bagi siapapun yang mengalami tindakan kekerasan.

Kata Kunci : Tindak Pidana, Kekerasan, Guru Dan Dosen

\section{PENDAHULUAN}

Guru adalah seorang pendidik yang berada di lingkungan sekolah yang bertugas memberikan pelajaran kepada seorang murid. Dan akhir-akhir ini banyak sekali perbuatan tidak menyenangkan yang dilakukan oleh oknum guru ketika mendidik muridnya. Perbuatan tidak menyenangkan sendiri merupakan suatu perbuatan yang dilakukan oleh seseorang atau si pelaku baik di sengaja atau pun tidak sengaja dengan melawan hukum, Baik memaksa orang lain ataupun menyuruh melakukan sesuatu dengan mengabaikan hak-hak si korban, sehingga korban atau si penderita tidak bisa berbuat apa-apa. Dan akibat dari perbuatan pelaku tersebut menimbulkan luka psychis bagi korban. ${ }^{1}$

Tindakan kekerasan yang terjadi di lingkungan masyarakat semakin meresahkan. Dalam menyelesaikan suatu konflik atau permasalahan disertai dengan tindakan kekerasan. Secara umum, tindakan kekerasan dapat diartikan penggunaan secara sengaja kekuatan fisik atau kekuatan, ancaman atau kekerasan aktual terhadap diri sendiri, orang lain, atau terhadap kelompok atau komunitas, yang berakibat luka atau kemungkinan besar bisa melukai, mematikan, membahayakan psikis, pertumbuhan yang tidak normal atau kerugian. Bentuk kekerasan banyak ragamnya, meliputi kekerasan fisik, kekerasan verbal, kekerasan psikologis, kekerasan ekonomi, kekerasan simbolik dan penelantaran. Kekerasan dapat dilakukan oleh perseorangan maupun secara berkelompok, secara serampangan (dalam kondisi terdesak) atau teroganisir. Dalam konteks sosial munculnya teori kekerasan dapat terjadi oleh beberapa hal yaitu sebagai berikut ${ }^{2}$ :

1) Situasi sosial yang memungkinkan timbulnya kekerasan yang disebabkan oleh struktur sosial tertentu.

2) Tekanan sosial, yaitu suatu kondisi saat sejumlah besar anggota masyarakat merasa bahwa banyak nilai dan norma yang sudah dilanggar. Tekanan ini tidak cukup menimbulkan kerusuhan atau kekerasan, tetapi juga menjadi pendorong terjadinya kekerasan.

3) Berkembangnya perasaan kebencian yang meluas terhadap suatu sasaran tertentu. Sasaran kebencian itu berkaitan dengan faktor pencetus, yaitu peristiwa yang memicu kekerasan.

4) Mobilisasi untuk beraksi, yaitu tindakan nyata berupa pengorganisasian diri untuk bertindak. Tahap ini merupakan tahap akhir dari akumulasi yang memungkinkan terjadinya kekerasan.

5) Kontrol sosial, yaitu tindakan pihak ketiga seperti aparat keamanan untuk mengendalikan, menghambat, dan mengakhiri kekerasan

Penyebab kekerasan terhadap peserta didik bisa terjadi karena guru tidak paham akan makna kekerasan dan akibat negatifnya. Guru mengira bahwa murid akan jera karena hukuman fisik.

\footnotetext{
${ }^{1}$ Hasbullah,2012. Dasar-dasar Ilmu Pendidikan, PT Raja Grafindo Persada, Jakarta. hlm 54.

${ }^{2}$ http://firdhamodest.blogspot.com/2012/04/normal-0-false-false-false-in-x-none-x.html, makalah Teori Kekerasan, diakses tanggal 18 Agustus 2017
} 
Sebaliknya, murid menjadi benci dan tidak patuh lagi pada guru. Kekerasan dalam pendidikan terjadi dikarenakan kurangnya kasih sayang dari guru. Guru memperlakukan murid sebagai subyek. Kekerasan bisa terjadi karena guru sudah tidak atau sangat kurang memiliki rasa kasih sayang terhadap murid, atau dahulu guru itu sendiri diperlakukan dengan keras. Sekolah yang seharusnya menjadi tempat untuk berprestasi, tetapi menjadi ajang premanisme.

Anak adalah tunas, potensi dan generasi penerus cita-cita bangsa, memiliki peran strategis dalam menjamin eksistensi bangsa dan negara di masa mendatang, agar mereka kelak mampu memikul tanggung jawab itu, maka mereka perlu mendapat kesempatan yang seluas-luasnya untuk tumbuh dan berkembang secara optimal, baik fisik, mental, sosial, spiritiual. Mereka perlu mendapatkan hak-haknya, perlu dilindungi dan disejahterahkan. Karenanya segala bentuk kekerasan pada anak perlu dicegah dan diatasi. ${ }^{3}$

Status dan kondisi Anak Indonesia adalah paradoks. Secara ideal, anak adalah pewaris dan pelanjut masa depan bangsa. Secara real, situasi anak Indonesia masih dan terus memburuk. Dunia anak semestinya diwarnai oleh kegiatan bermain, belajar, dan mengembangkan minat serta bakatnya untuk masa depan, realitasnya diwarnai data kelam dan menyedihkan. Anak Indonesia masih dan terus mengalami kekerasan. ${ }^{4}$

Belakangan ini banyak terjadi berbagai macam kasus yang terjadi di lingkungan pendidikan yang berhubungan dengan kekerasan yang dilakukan oleh guru terhadap anak didiknya. Kebanyakan dari kasus yang terjadi disebabkan oleh penerapan norma kedisplinan yang terlalu dipaksakan terhadap anak didik. Sedangkan tidak semua anak didik terbiasa dengan perilaku disiplin. Cara penanaman kedisplinan yang salah dapat berupa terjadinya kekerasan baik fisik maupun mental terhadap anak. Hal yang paling terlihat adalah kekerasan fisik. Tidak jarang hal ini sampai ke pengadilan karena orang tua siswa merasa di rugikan. ${ }^{5}$

Kekerasan terhadap anak seringkali diidentifisikan dengan kekerasan kasat mata, seperti kekerasan fisik dan seksual. Padahal kekerasan yang bersifat psikis dan sosial (struktural) juga membawa dampak buruk dan permanen terhadap anak. Karenanya istilah child abuse atau perlakuan salah terhadap anak bisa dimulai dari yang bersifat fisik (physicalabuse) hingga seksual (sexual abuse); dari yang psikis (mental abuse) hingga sosial (social abuse) yang berdimensi kekerasan struktural. Kemiskinan seringkali bergandeng dengan rendahnya tingkat pendidikan, pengangguran dan tekanan mental umumnya dipandang sebagai faktor dominan yang mendorong terjadinya kasus kekerasan terhadap anak. Lemahnya penegakan hukum dan praktik budaya bisa pula berdampak pada fenomena kekerasan terhadap anak.

Berdasarkan hasil penelitian yang dilakukan oleh UNICEF (2006) di beberapa daerah di Indonesia menunjukkan bahwa sekitar $80 \%$ kekerasan yang terjadi pada siswa dilakukan oleh guru. Belakangan ini masyarakat dikejutkan dengan berita mengenai seorang guru yang menganiaya salah satu siswanya, akibatnya siswa tersebut harus dirawat di rumah sakit. Kita tahu bahwa sekolah merupakan tempat siswa menimba ilmu pengetahuan dan seharusnya menjadi tempat yang aman bagi siswa. Namun ternyata di beberapa sekolah terjadi kasus kekerasan pada siswa oleh guru. ${ }^{6}$

Berdasarkan alasan tersebut di atas, penulis berkeinginan untuk melakukan penelitian yang

\footnotetext{
${ }^{3}$ Abu Huraerah,2007. Child Abuse (kekerasan terhadap anak), Edisi Revisi, Penerbit Nuansa, Bandung, hlm: 11

${ }^{4}$ Suparno, Paul,2004. Guru Demokratis Di Era Reformasi Pendidikan, Grasiondo, Jakarta,. hlm 21

5 Wiwit Nurasih,"Maraknya Kasus Kekerasan Di Dunia", dalam http://wiwitna.blogspot.com/2013/03/maraknyakasus-kekerasan-di-dunia.html. diakses pada tanggal 18 Agustus 2017.

${ }^{6}$ Pendidikan UNICEF dalam Yanuar, Andy, "Tindak Kekerasan Guru Terhadap Siswa Pada Saat Pembelajaran"dalam, http://surabaya.detik.com/read/2009/12/15/141237/1260501/475/digampar-guru-siswapamekasan-ngakutelinganya-berdengung, diakses pada 18 Agustus 2017.
} 
berjudul : "Tindak Pidana Kekerasan Dalam Proses Belajar Mengajar Ditinjau Dari Perspektif Hukum Pidana Dan Undang-Undang Nomor 14 Tahun 2005 Tentang Guru Dan Dosen”.

Dari uraian tersebut diatas dapat dirumuskan suatu permasalahan sebagai berikut: 1) Bagaimana tindak pidana kekerasan dalam proses belajar mengajar dalam perspektif hukum pidana dan Undang-Undang No. 14 Tahun 2005 tentang Guru dan Dosen? 2) Apa kelemahan-kelemahan tindak pidana dalam proses belajar mengajar dalam perspektif hukum pidana dan Undang-Undang No. 14 Tahun 2005 tentang Guru dan Dosen? 3) Bagaimanakah solusi tindak pidana dalam proses belajar mengajar dalam perspektif hukum pidana dan Undang-Undang No. 14 Tahun 2005 tentang Guru dan Dosen?

\section{Metode Penelitian}

Jenis penelitian yang dipergunakan dalam menyelesaikan tesis ini adalah metode penelitian yuridis normatif bersifat deskriptif analisis, yaitu penelitian yang dilakukan dengan cara meneliti bahan pustaka (data sekunder) atau penelitian hukum perpustakaan ${ }^{7}$.

Menurut Soerjono Soekanto dan Sri Mamudji, Penelitian hukum normatif meliputi penelitian terhadap asas-asas hukum, taraf sinkronisasi hukum ${ }^{8}$ Pendekatan penelitian yang digunakan Pendekatan penelitian yang digunakan dalam penelitian ini adalah penelitian hukum empiris atau biasa disebut penelitian yuridis empiris. Dalam penelitian ini, hukum dikonsepkan sebagai suatu gejala empiris yang dapat diamati di dalam kehidupan nyata.

Jenis data yang digunakan adalah data primer dan sekunder. Untuk memperoleh data primer peneliti mengacu terhadap data atau fakta-fakta dan kasus hukum yang diperoleh langsung melalui penelitian di lapangan termasuk keterangan dari responden yang berhubungan dengan objek penelitian dan praktik yang dapat dilihat serta berhubungan dengan obyek penelitian. Sementara data sekunder dilakukan dengan cara studi kepustakaan. Data sekunder ini berguna sebagai landasan teori untuk mendasari penganalisaan pokok-pokok permasalahan yang ada dalam penelitian ini. Data sekunder dalam penelitian ini meliputi :

a. Bahan hukum primer, yang terdiri dari : 1) Undang-Undang Dasar 1945; 2) KUHP; 3) KUHAP; 4) Undang-Undang Nomor 20 tahun 2003 tentang Sistem Pendidikan Nasional; 5) Undang-Undang Nomor 23 tahun 2002 tentang Perlindungan Anak; 6) Undang-Undang Nomor 4 tahun 1979 tentang Kesejahteraan Anak; 7) Undang-Undang Nomor 14 Tahun 2005 tentang Guru dan Dosen.

b. Bahan hukum sekunder. Buku-buku, dokumen hasil penelitian di bidang hukum khususnya masalah Tindak Pidana Kekerasan Dalam Proses Belajar Mengajar.

c. Bahan Hukum Tersier, yang terdiri dari : Kamus Bahasa Indonesia, Kamus Bahasa Inggris, Kamus Hukum, Ensiklopedia serta sarana ajar (hand out) tentang tata cara penulisan karya ilmiah.

Pengumpulan data difokuskan pada yang ada, sehingga dalam penelitian ini tidak menyimpang dan kabur dalam pembahasannya. Penelitian ini menggunakan Library Research (studi kepustakaan) yaitu pengumpulan data yang diperoleh dari sumber-sumber literature, karya ilmiah, peraturan perundang-undangan serta sumber-sumber tertulis lainnya yang berhubungan dengan masalah yang diteliti sebagai landasan teori. Dari penelitian ini data yang diperoleh disebut data sekunder.

Metode analisa data yang digunakan adalah analisa normatif, yaitu dengan memperhatikan fakta-fakta yang ada dalam praktek lapangan yang kemudian dibandingkan dengan uraian yang

\footnotetext{
7 Ediwarman, Monograf, Metodologi Penelitian Hukum, Medan: Program Pascasarjana Univ. Muhammadiyah Sumatera Utara, Medan, 2010, hal. 24

8 Soerjono Soekamto dan Sri Mamudji, Penelitian Hukum Normatif suatu Tinjauan Singkat Jakarta: Raja Grafindo Persada, 2001 hal. 13-14
} 
didapat dari studi kepustakaan. Dari analisis tersebut dapat diketahui efektifitas sistem hukum yang bersifat edukatif terhadap masyarakat dalam mengetahui Tindak Pidana Kekerasan Dalam Proses Belajar Mengajar.

Sebagai cara untuk menarik kesimpulan dari hasil penelitian yang sudah terkumpul, metode analisa data yang digunakan adalah Normatif Kualitatif. Normatif karena penelitian ini bertitik tolak dari peraturan - peraturan yang ada sebagai norma hukum positif, sedangkan kualitatif maksudnya analisa data yang bertitik tolak pada informasi-informasi yang didapat dari responden untuk mencapai kejelasan masalah yang akan dibahas.

\section{HASIL PENELITIAN DAN PEMBAHASAN}

\section{Tindak Pidana Kekerasan Dalam Proses Belajar Mengajar Dalam Perspektif Hukum Pidana dan Undang-Undang No. 14 Tahun 2005 Tentang Guru dan Dosen}

Hukum pidana ialah hukum yang mengatur tentang pelanggaran-pelanggaran dan kejahatankejahatan terhadap kepentingan umum, perbuatan mana diancam dengan hukuman yang merupakan suatu penderitaan atau siksaan ${ }^{9}$.

Hukum pidana, secara umum berfungsi untuk mengatur kehidupan masyarakat agar dapat tercipta dan terpeliharanya ketertiban umum. Manusia dalam usahanya untuk memenuhi kebutuhan dan kepentingan hidupnya yang berbeda-beda terkadang mengalami pertentangan antara satu dengan yang lainnya, yang dapat menimbulkan kerugian atau mengganggu kepentingan orang lain. Agar tidak menimbulkan kerugian dan mengganggu kepentingan orang lain dalam usaha memenuhi kebutuhan hidupnya tersebut maka hukum memberikan aturan-aturan yang membatasi perbuatan manusia, sehingga ia tidak bisa berbuat sekehendak hatinya. ${ }^{10}$

Dalam kegiatan belajar mengajar, adanya pemberian hukuman merupakan suatu hal yang biasa yang dilakukan oleh guru sejak dari dulu dalam rangka mendisiplinkan anak didik (murid) dari perbuatan yang tidak baik. Namun seringkali dikarenakan kurangnya komunikasi antara anak didik (murid) dengan siswa tentang pemberian hukuman oleh guru ini, perbuatan tersebut dianggap sebagai suatu tindakan kekerasan. Dalam hal ini dapat dikategorikan sebagai kekerasan anak secara fisik. Kekerasan anak secara fisik adalah penyiksaan, pemukulan, dan penganiayaan terhadap anak, dengan atau tanpa menggunakan benda-benda tertentu, yang menimbulkan luka-luka fisik atau kematian pada anak. Bentuk luka dapat berupa lecet atau memar akibat persentuhan atau kekerasan benda tumpul, seperti bekas gigitan, cubitan, ikat pinggang atau rotan. Dapat pula berupa luka bakar akibat bensin panas atau berpola akibat sundutan rokok atau setrika dan lokasi luka biasanya ditemukan pada daerah paha, lengan, mulut, pipi, dada, perut, punggung atau daerah bokong. ${ }^{11}$

Dalam Kitab Undang-undang Hukum Pidana Pasal 89 berbunyi: Yang disamakan melakukan kekerasan itu, membuat orang jadi pingsan atau tidak berdaya lagi (lemah). Menurut R.Soesilo penjelasan Pasal 89 KUHP di atas, melakukan kekerasan artinya mempergunakan tenaga atau kekuatan jasmani tidak kecil secara yang tidak sah, misalnya memukul dengan tangan atau dengan segala macam senjata, menyepak, menendang, dan sebagainya. Yang disamakan dengan "melakukan

\footnotetext{
${ }^{9}$ C.S.T. Kansil dan Christine S.T. Kansil,2007. Pokok-Pokok Hukum Pidana : Hukum Pidana Untuk Tiap Orang, Cet 2, PT.Pradnya Paramit, Jakarta.hal. 3

${ }^{10}$ Chazawi, Adami. 2002, Pelajaran Hukum Pidana Bagian I, PT RajaGrafindo Persada. Jakarta, hlm. 3

11 B.Uno, Hamzah. 2009, Profesi Kependidikan Problema, Solusi, dan Reformasi Pendidikan di Indonesia, Bumi Aksara. Jakarta. hlm. 34
} 
kekerasan" menurut Pasal 89 KUHP adalah membuat orang jadi pingsan atau tidak berdaya. ${ }^{12}$

Dalam Undang-Undang Nomor 23 Tahun 2002 Tentang Perlindungan anak, sebagai peraturan khusus tentang anak, perbuatan guru yang diindikasikan sebagai tindak pidana diancam dengan Pasal 80 ayat (1) yang menyebutkan: Setiap orang yang melakukan kekejaman, kekerasan atau ancaman kekerasan atau penganiyaan terhadap anak, dipidana dengan pidana penjara paling lama tiga tahun enam bulan dan/atau denda paling banyak Rp. 72.000.000,00 (tujuh puluh dua juta rupiah).

\section{Kelemahan-Kelemahan Tindak Pidana Dalam Proses Belajar Mengajar Dalam Perspektif Hukum Pidana dan Undang-Undang No. 14 Tahun 2005 Tentang Guru dan Dosen.}

Kondisi dan latar belakang tindak kekerasan dalam pendidikan terangkai dalam hubungan yang bersifat spiral, dapat muncul sewaktu-waktu, oleh pelaku siapa saja yang terlibat dalam lembaga pendidikan, sepanjang dijumpai adanya pemicu kejadian. Menurut Eric Hoffer, pemicu kekerasan utamanya adalah hal-hal mempersatukan gerakan massa, seperti rasa benci kolektif, perilaku meniru rekannya, bujukan pihak tertentu, karena ajakan pemimpin atau yang ditokohkan, karena adanya aksi pembuka kekerasan, adanya unsur kecurigaan, dan upaya penggalangan atau persatuan massa. Sedangkan unsur pendorong timbulnya aksi bersama adalah keterikatan dengan kelompok (gank, club, dan sebagainya), perilaku pura-pura atau bergaya, frustasi atau meremahkan kondisi masa kini, unsur supranatural atau "hal yang tak nampak dan hal yang nampak", doktrin yang diyakininya, dan karena gerakan massa itu sendiri. Pelaku ataupun korban menyangkut guru dan atau pimpinan sekolah, pelajar, dan masyarakat ${ }^{13}$.

Dengan definisi guru yang memberikan sanksi fisik kepada peserta didik di lingkungan sekolah telah dapat dinyatakan sebagai pelaku tindak pidana penganiyaan. Karena guru tersebut telah memenuhi unsur penganiyaan ${ }^{14}$ :

1) Dengan sengaja, yakni menghendaki terjadinya perbuatan tersebut atau mengetahui bahwa perbuatan tersebut merupakan perbuatan yang dilarang menurut hukum. Dengan kata lain, seseorang dikatakan melakukan suatu perbuatan dengan sengaja jika perbuatan tersebut dilakukan dengan menghendaki dan mengetahui. Seseorang yang melakukan perbuatan pidana telah menyadari bahwa akibat dari perbutannya bisa sesuai dengan kehendak atau tujuan, maupun tidak sesuai dengan kehendak atau tujuan.

2) Perbuatan yang dilakukan telah menimbulkan rasa sakit, tentu sanksi fisik yang diberikan guru kepada peserta didik mengakibatkan rasa sakit.

Demikian juga dalam putusan Mahkamah Agung Tahun 2016, dengan pokok perkara tentang seorang guru yang memotong rambut 4 muridnya yang panjang, salah satu murid tidak terima dan memukul guru tersebut bersama dengan orangtuanya. Putusan pengadilan negeri menyatakan bahwa guru tersebut telah terbukti melakukan tindak pidana dengan pidana percobaan, Putusan Pengadilan Tinggi juga demikian, menguatkan Putusan Pengadilan Negeri. Sedangkan Putusan Mahkamah Agung membebasakan guru tersebut dengan pertimbangan "Apa yang dilakukan terdakwa (guru) adalah sudah menjadi tugasnya dan bukan merupakan suatu tindak pidana dan terdakwa tidak dapat dijatuhi pidana atas perbuatan atau tindakannya tersebut karena bertujuan untuk mendidik agar menjadi murid yang baik dan berdisiplin". Pertimbangan Mahkamah Agung tersebut tidak jauh berbeda dengan Arrest Hooge Raad tanggal 10 Februari 1902 yang mempertimbangkan "Jika menimbulkan

\footnotetext{
${ }^{12}$ R. Soesilo. 1994, Kitab Undang-Undang Hukum Pidana Serta Komentar - Komentar Lengkap dengan Pasal demi Pasal, Politea. Bogor. hlm. 14

${ }^{13}$ Widiastono, Tony D. 2004, Pendidikan Manusia Indonesia, Penerbit Buku Kompas. Jakarta. hlm. 11

${ }^{14}$ Hiariej, Eddy O.S. 2014. Prinsip-Prinsip Hukum Pidana. Cahaya Atma Pustaka.Yogyakarta. hlm. 31
} 
luka atau sakit pada tubuh bukan menjadi tujuan, melaikan suatu sarana belaka untuk mencapai suatu tujuan yang patut, maka tidaklah ada penganiayaan". ${ }^{15}$

Jadi guru yang memberikan sanksi fisik kepada peserta didik di sekolah bukan merupakan tindak pidana dan tidak dapat dimintai pertanggungjawaban pidana semampang sanksi fisik tersebut hanya sebagai sarana untuk mendidik dan mendisiplinkan peserta didik serta sanksi fisik yang diberikan dalam koridor dan batas kewajaran.

\section{Solusi Tindak Pidana Dalam Proses Belajar Mengajar Dalam Perspektif Hukum Pidana dan Undang- Undang No. 14 Tahun 2005 tentang Guru dan Dosen}

Karena sekolah dan guru yang kurang tegas maka murid jadi bebas sehingga tidak mengindahkan norma-norma dan peraturan yang ada. Misalnya murid akan berpenampilan seenaknya sendiri seperti preman atau spg, bebas bolos sekolah tanpa hukuman yang berat, bebas melakukan kenakalan di luar batas kewajaran, meremehkan guru, dan lain sebagainya.

Oleh karena itulah maka diperlukan peran pemerintah untuk membuat standar pendidikan yang baik yang dapat membuat murid takut dalam artian yang baik. Guru seharusnya boleh menghukum siswa yang nakal dan tidak disiplin dengan sedikit kekerasan dan hukuman fisik agar para siswa-siswi takut dan terpacu untuk belajar, patuh, taat, hormat, disiplin, bertanggung jawab, tahu aturan, dan lain sebagainya.

Beberapa solusi yang diberikan untuk mengatasi kekerasan pada siswa di sekolah diantaranyan adalah sebagai berikut:

a. Menerapkan pendidikan tanpa kekerasan di sekolah

b. Mendorong/mengembangkan humanisasi pendidikan dengan cara-cara :

1) Menyatupadukan kesadaran hati dan pikiran.

2) Membutuhkan keterlibatan mental dan tindakan sekaligus.

3) Suasana belajar yang meriah,gembira dengan memadukan potensi fisik, psikis, menjadi suatu kekuatan yang integral.

c. Hukuman yang di berikan berkolerasi dengan tindakan anak,

d. Terus menerus membekali guru untuk menambah wawasan pengetahuan, kesempatan, pengalaman baru untuk mengembangkan kreativitas mereka.

e. Konseling.Bukan siswa saja membutuhkan konseling, tapi juga guru. Sebab guru juga mengalami masa sulit yang membutuhkan dukungan, penguatan, atau bimbingan untuk menemukan jalan keluar yang terbaik.

f. Segera memberikan pertolongan bagi siapa pun juga yang mengalami tindakan kekerasan di sekolah,dan menindak lanjuti serta mencari solusi alternatif yang terbaik.

\section{PENUTUP}

1. Pemberian sanksi fisik oleh guru kepada peserta didik dalam prespektif hukum pidana bukan merupakan tindak pidana dan tidak dapat dipertanggungjawabkan pidana, semampang sanksi fisik tersebut merupakan sarana untuk meningkatkan edukasi dan kedisiplinan peserta didik.

2. Pada era sekarang ini banyak aduan kekerasan guru terhadap peserta didik, guru yang memberikan sanksi fisik kepada peserta didik di sekolah bukan merupakan tindak pidana dan tidak dapat dimintai pertanggungjawaban pidana semampang sanksi fisik tersebut hanya sebagai sarana untuk mendidik dan mendisiplinkan peserta didik serta sanksi fisik yang diberikan dalam koridor dan batas

\footnotetext{
${ }^{15}$ Nurdin, Syafruddin. Dan Usman. Basyiruddin. 2002. Guru Profesional \& Implementasi Kurikulum. Ciputat Pers. Jakarta. hlm 10
} 
kewajaran..

3. Solusi tindak pidana dalam proses belajar mengajar adalah : a. Menerapkan pendidikan tanpa kekerasan. b. Mendorong atau mengembangkan humanisasi pendidikan. c. Hukuman yang diberikan berkorelasi dengan tindakan anak. d. Membekali guru dengan wawasan pengetahuan. e. Konseling. f. Segera memberikan pertolongan bagi siapapun yang mengalami tindakan kekerasan.

\section{DAFTAR PUSTAKA}

Abu Huraerah,2007. Child Abuse (kekerasan terhadap anak), Edisi Revisi, Penerbit Nuansa, Bandung.

B.Uno, Hamzah. 2009, Profesi Kependidikan Problema, Solusi, dan Reformasi Pendidikan di Indonesia, Bumi Aksara. Jakarta.

C.S.T. Kansil dan Christine S.T. Kansil,2007. Pokok-Pokok Hukum Pidana : Hukum Pidana Untuk Tiap Orang, Cet 2, PT.Pradnya Paramit, Jakarta.

Chazawi, Adami. 2002, Pelajaran Hukum Pidana Bagian I, PT RajaGrafindo Persada. Jakarta.

Ediwarman, 2010, Monograf, Metodologi Penelitian Hukum, Medan: Program Pascasarjana Univ. Muhammadiyah Sumatera Utara, Medan.

Hasbullah,2012. Dasar-dasar Ilmu Pendidikan, PT Raja Grafindo Persada, Jakarta.

Hiariej, Eddy O.S. 2014. Prinsip-Prinsip Hukum Pidana. Cahaya Atma Pustaka.Yogyakarta.

Nurdin, Syafruddin. Dan Usman. Basyiruddin. 2002. Guru Profesional \& Implementasi Kurikulum. Ciputat Pers. Jakarta.

R. Soesilo. 1994, Kitab Undang-Undang Hukum Pidana Serta Komentar - Komentar Lengkap dengan Pasal demi Pasal, Politea. Bogor.

Soerjono Soekamto dan Sri Mamudji, 2001. Penelitian Hukum Normatif suatu Tinjauan Singkat Jakarta: Raja Grafindo Persada.

Suparno, Paul,2004. Guru Demokratis Di Era Reformasi Pendidikan, Grasiondo, Jakarta.

Widiastono, Tony D. 2004, Pendidikan Manusia Indonesia, Penerbit Buku Kompas. Jakarta.

Undang-Undang Nomor 14 Tahun 2005 tentang Guru dan Dosen

http://firdhamodest.blogspot.com/2012/04/normal-0-false-false-false-in-x-none-x.html

http://wiwitna.blogspot.com/2013/03/maraknya-kasus-kekerasan-di-dunia.html

http://surabaya.detik.com/read/2009/12/15/141237/1260501/475/digampar-guru-siswapamekasanngaku-telinganya-berdengung 